\title{
The incidence of agricultural support on trade of refined sugar
}

\author{
Malick Diarrassouba \\ Legislative Fiscal Office, Room 1007 State Capitol, Lincoln, NE 68509 USA
}

Email address:

mdiarrassouba@leg.ne.gov

\section{To cite this article:}

Malick Diarrassouba. The Incidence of Agricultural Support on Trade of Refined Sugar. International Journal of Business and Economics Research. Vol. 2, No. 3, 2013, pp. 77-83. doi: 10.11648/j.ijber.20130203.15

\begin{abstract}
This paper investigates the impact of the market price support on trade of refined sugar. We use a balanced panel of bilateral trade data are on exports of refined sugar among 22 countries over the period 1995-2007. We employ the theoretical motivated gravity model and spatial econometric techniques to account for spatial interdependence among trade flows. Results suggest that ignoring the spatial dependence in the cross sectional change the magnitude and statistical significance of the estimated parameters. Our results also indicate the benefit of the reduction in the market price support to increase trade of refined sugar.
\end{abstract}

Keywords: Spatial Econometric, Market Price Support, Spatial Fixed Effects

\section{Introduction}

Sugar is produced in more than 100 countries, and is one of the heavily regulated commodities, particularly in OECD countries with the worst offenders the European Union (EU), the United States (US), and Japan through domestic support, export subsidies, and import quotas for the purpose of transferring income to farmers (Elobeid and Beghin 2006). For example, Japan protects its sugar market through a mix of producer price support and tariffs on imports. The US tools are the loan program and import restrictions. The EU uses import restrictions, limited market access, and subsidization ofexports to protect its sugar producers. While such policies achieve their goal of protecting producers, they have large effects on world sugar markets by (1) depressing the world price, (2) increasing world price variability, and (3) reducing the volume of international trade.

In 1994, the Uruguay Round Agreement on Agriculture (URAA) under the General Agreement on Tariffs and Trade (GATT) mandated its members to reduce domestic support and export subsidies, and to facilitate market access to lessen distortion in the world sugar market and to increase export opportunities for more efficient producers. The URRA classified these policies in three "boxes" according to their impact on international trade. Those policies deemed to have the least distorting trade effect are placed in the "green" box and are exempt from reduction; those policies that aggregate programs measured by the aggregate measure of support (AMS) judged to be trade distorting are placed in the "amber" box and are subject to reduction; finally the "blue" box refers to policies that provide support programs intended to limit production and are not included in the AMS, making them exempt from reduction.

The AMS is based on the Producer Support Estimate (PSE) primarily used by the Organization for Economic Cooperation and Development (OECD) countries to monitor and evaluate agricultural policies by country and specific commodity. As mentioned by Legg (2003), the PSE is defined since 1990 as "an indicator of the annual monetary value of gross transfers from consumers and taxpayers to agricultural producers, measured at the farm level, arising from policy measures that support agriculture, regardless of their nature, objectives or impacts on farm production or income. The PSE includes market price support, payments based on output, payments based on input used, and payments based on historical entitlements (OECD 2001). Oskam and Meester (2006) argued that the major agricultural support in OECD countries is the market price support. It is defined as the annual monetary value of gross transfers from consumers and taxpayers to agricultural producers arising from policy measures that create a gap between domestic market and border prices of the specific agricultural commodity measured at the farm gate level (OECD 2001, Legg 2003). Put differently, 
consumers support agriculture by paying higher market prices resulting from supply restrictions such as imports quotas, imports tariffs and export subsidies.

Numerous studies have investigated the impact of agricultural support on the sugar market.Using the Global Sweetener Market (GSM), model Borrell and Pearce (1999) examined the impact of multilateral liberalization in the sugar markets for 24 regions, and they found a $38 \%$ increase in world sugar price under a free trade scenario. Koo (2002) analyzed how agricultural support in the US and EU affect the world sugar price. He found that liberalizing the US and EU sugar markets would lead to a $68.2 \%$ increase in the world sugar price, and a $4.7 \%$ decrease in the US wholesale sugar price. Elobeid and Beghin (2006) examined the effects of agricultural support and trade policies on the sugar market in OECD and nonOECD countries within a partial equilibrium framework. Their study showed that the removal of domestic policies and trade distortions would increase the world sugar price by $48 \%$. Additionally, their results indicated that the higher world sugar price induces a lower domestic sugar price on average by $40 \%$ and $62 \%$ in the EU and Japan respectively, and by $9 \%$ on average in the US. While these studies have examined the impact of various agricultural and trade policies on sugar trade, none of them has considered the role of spatial relationship across geographically close countries in explaining the incidence of market price support on trade of refined sugar despite the presence of processing industries that process raw sugar into white sugar.

This paper contributes to the literature by investigating the effect of the market price support on trade of refined sugar using a spatial econometric framework. An advantage of the spatial econometric framework is to control for spatial interdependence across trade flows. In addition, the application of the spatial econometrics method to trade data is a new area for researchers as opposed to the ordinary least squares (OLS). The results suggest the benefit in the reduction of the market price support in order to increase trade of refined sugar.

The remainder of the paper is organized as follows. In Section 2, we provide an analysis of the market price support. Section 3 presents the methodology and data. Section 4 discusses the empirical results, and Section 5 concludes.

\section{Analysis of Market Price Support}

Given that market price support to farmers increases both domestic producer and consumer prices, a relevant question is what would be the effect of the market price on trade for refined sugar. This point is illustrated in Figure 1a, $1 \mathrm{~b}$ and 1c which show an analysis of the market price support for an exporting large country.
Figure 1(a) depicts the raw sugar market with supply (S), demand (D), and the price of raw sugar ( $\left.\operatorname{Pr}^{*}\right)$. Figure 1(b) is the market for refined sugar with supply ( $\mathrm{Sd})$, demand (Dd), and price $(\mathrm{Pd})$. Figure 1(c) represents the international market with excess supply schedule (ES), world excess demand (Dw), and the world price ( $\mathrm{Pw})$. In this analysis, I assume that $\mathrm{Pd}^{*}$ and $\mathrm{Pw}^{*}$ are equal in order to evaluate how an increase in the market price support affects all markets.

Consider the absence of market price support. In the raw sugar market, production is Q and price $\mathrm{Pr}^{*}$. In the refined sugar market, the country produces $\mathrm{S}^{*}$ and consumes $\mathrm{D}^{*}$ at price $\mathrm{Pd}$, and exports the surplus equal to $\mathrm{X}^{*}$ in the international market at price $\mathrm{Pd}^{*}=\mathrm{Pw}^{*}$.

If there is government intervention in agriculture through market price support, domestic producers increase production of raw sugar from $\mathrm{Q}$ to $\mathrm{Q}$,' while the price rises from Pr* to Pr'. The high price raw sugar is transmitted to the refining sugar industries by increasing their production costs. This is seen by the leftward shift of the refined sugar supply schedule from $\mathrm{Sd}$ to $\mathrm{Sd}$ ' increasing the price from $\mathrm{Pd}^{*}$ to $\mathrm{Pd}$ '. As a result, the country's production of refined sugar decreases from $S^{*}$ to $S^{\prime}$ associated with the reduction of domestic consumption from $\mathrm{D}^{*}$ to $\mathrm{D}^{\prime}$. As the refined sugar supply schedule shifts leftward, the excess supply curve also shifts leftward from ES to ES' in the international market. As a result, exports of refined sugar fall from $\mathrm{X}^{*}$ to $\mathrm{X}^{\prime}$ and the world price increases from $\mathrm{PW}^{*}$ to Pw'. There is a distortion in the country's volume of trade due to an increase in the market price support in the form of lower exports and higher domestic price as well as higher world price.

\section{Methodology and Data}

The gravity model has become the workhorse of empirical international trade studies despite initial questions about its theoretical foundations. Anderson (1979) provided the first theoretical foundation of the gravity model based on constant elasticity of substitution (CES) preferences. Bergstrand (1990) and Deardoff (1998) have also contributed to improve the theoretical foundation of the gravity model with trade theories based on models of imperfect competition in the context of Heckscher-Ohlin model.

Although incomes and distance are important to predict the magnitude of bilateral trade flows, other variables such as dummies may be added to the model to indicate membership to an economic area, protection levels, historical ties and border effects. I also include market price support to represent domestic support for farmers. The gravity model is specified in the natural logarithms as follows:

$$
\begin{aligned}
& \ln x_{i j}=\alpha_{0}+\alpha_{1} \operatorname{lnGDP_{i}}+\alpha_{2} \ln G D P_{j}+\alpha_{3} \text { lndist }_{i j}+\alpha_{4} \operatorname{lang}_{i j} \\
& +\alpha_{5} \text { cont }_{i j}+\alpha_{6} \operatorname{lnMPS}_{i}+\alpha_{7} \operatorname{lnMPS} S_{j}+\alpha_{8} N A F T A_{i j}+\alpha_{9} E U_{i j}+\varepsilon_{i j}
\end{aligned}
$$


where subscript $i$ denotes the exporter and $j$ is the importer. $\mathrm{Xij}$ is the dollar value of country $\mathrm{i}$ exports to country $\mathrm{j}$, GDPi and GDPj are gross domestic products of countries $\mathrm{i}$ and $\mathrm{j}$ expressed as dollar value. Distij is the distance between the economic centers of countries $i$ and $j$, langij is a language dummy variable taking the value of 1 if $\mathrm{i}$ and $\mathrm{j}$ share a common language and 0 otherwise, Contij is a dummy variable assuming the value of 1 if $i$ and $\mathrm{j}$ share a land border and 0 otherwise. EU and NAFTA are dummies variables taking the value of 1 if $i$ and $j$ both belong to the same regional trade agreement and 0 otherwise, MPSi and MPSj are market price support of the respective countries expressed in million US dollar by using US\$ exchange rate.The error term eij captures any

$$
\ln \left(\frac{x_{i j t}}{\operatorname{GDP}_{i t} G D P P_{j t}}\right)=\alpha_{0}+\alpha_{i t}+\alpha_{j t}+\alpha_{i j}+\alpha_{1} \ln M P S_{i t}+\alpha_{2} \ln M P S_{j t}+\alpha_{3} N A F T A_{i j}+E U_{i j}+\varepsilon_{\mathrm{ijt}}
$$

where the subscript $\mathrm{t}$ denotes time; $\alpha_{i t}$ is the exporter-bytime fixed effect, $\alpha_{j t}$ is the importer -by -time fixed effect to control for the time varying multilateral resistance terms; $\alpha_{i j}$ denotes bilateral fixed effects to account for the variation in distance, language, and common border.

In spite of its empirical success in explaining trade flows, the gravity model has been criticized for not taking into account the notion of relative space or location (Porojan, 2001, LeSage and Pace 2008). Anselin (1988) pointed out that data collected from observations located in geographic space should incorporate spatial effects known as spatial dependence and spatial heterogeneity. Spatial heterogeneity describes the result of spatial processes that involves structural instability of the functional form or varying parameters, and heteroskedasticity as a consequence of omitted variables or other forms of misspecification. Spatial dependence takes two forms; the spatial autoregressive model or spatial lag model which is analogous to the lagged dependent variable model in times series regressions, and the spatial error model often called spatial autocorrelation with a non-spherical error term.Ignoring the spatial dependence across trade flows model violates the Gauss Markov assumptions and provides biased and inconsistent ordinary least squares (OLS) estimates. Therefore, inferences based on Ordinary Least Squares (OLS) estimates may be misleading.

Following Elhorst and Freret (2009), we apply the spatial fixed effects model because it captures all space - specific, time -invariant variables whose omission could bias the estimates in cross-sectional data. The spatial lag and spatial fixed effects is as follows.

$$
Y_{i j}=\rho W Y_{i j}+X \beta+\mu+\varepsilon_{t} E\left(\varepsilon_{t}\right)=0, E\left(\varepsilon_{t} \varepsilon_{t}{ }^{\prime}\right)=\sigma^{2} I_{N}
$$

where $Y_{i j}=\left(\ln X_{1 l}, \ldots \ldots, \ln X_{N T}\right)^{\prime}$ is a $(\mathrm{nx} 1)$ vector of exports; $X=\left(\ln G D P_{i}, \quad \ln G D P_{j}\right.$, lndist $_{i j,}$, lang $_{i j}, \quad \ln M P S_{i}$, $\operatorname{lnMPS}, N A F T A, E U)$ ' is a (nxk) vector of independent variables; $\beta$ is ( $\mathrm{k} \times 1)$ matching vector of unknown fixed parameters; $\varepsilon_{t}=\left(\begin{array}{llll}\varepsilon_{1 t} \ldots \ldots . . & \varepsilon_{l t}\end{array}\right)^{\prime}$ is $(\mathrm{n} \times 1) \quad$ vector and is assumed to be independently and identically distributed other shocks that may affect bilateral trade and assumes to be normally distributed. neglects the endogeneity problem that arises from unobserved time-invariant heterogeneity in trade flows between country pairs and the border effects as well. Building upon the work of Anderson and Wincoop (2003), Baier and Bergstrand (2007) derived the theoreticallymotivated gravity model using panel data with bilateral pair and country-by-time-fixed effects to control for omitted variables and endogenous policy variables. The theoretically- motivated gravity model then takes the following form:

(i.i.d) error terms; and $\mu=\left(\mu_{1} \ldots \ldots \ldots \mu_{N}\right)^{\prime}$ is $(\mathrm{nx} 1)$ vector that captures the effect of the omitted variables of each spatial unit;

$\rho$ is the spatial autoregressive coefficient and assumed to lie between-1 and 1, and measures the degree of linear dependence between $Y_{i j}$ and the weighted average of neighboring countries' exports. $\mathrm{W}$ is a first order spatial contiguity matrix of dimension $\mathrm{n} \times \mathrm{n}$.The $\mathrm{W}$ matrix indicates the degree of interdependence between any two observations in the space in which $\mathrm{W}_{\mathrm{ij}}=1$ for any two countries sharing a common border, and 0 otherwise. $W Y_{i j}$ is the spatially lagged dependent variable that captures neighborhood spillover effects. In other words, a country' exports will be associated to those exports in its nearby countries.

If equation (2a) is the correct specification, then ignoring the spatial autoregressive term is equivalent to an omitted variable error. Therefore, OLS coefficients estimates are biased and inconsistent and all statistical inferences are invalid. error model. The spatial error and spatial fixed effects is expressed as:

$$
Y_{i j}=X \beta+\mu+\Phi_{t}
$$

and the spatial error autocorrelation is reflected in the following error term:

$$
\Phi_{t}=\lambda W \Phi_{t}+\varepsilon_{t} \quad, E\left(\varepsilon_{t}\right)=0, E\left(\varepsilon_{t} \varepsilon_{t}^{\prime}\right)=\sigma^{2} I_{N}
$$

where $\mathrm{Y}_{\mathrm{ij}} \mathrm{X}, \mathrm{W}$ are defined in the same way as in equation (2a), $\lambda$ is the spatial autocorrelation coefficient and assumed to lie between -1 and 1. The coefficient $\lambda$ measures the effects of neighboring shocks embodied in the error term (Bernat, 1996). In equation (2c), ignoring the spatial autocorrelation $\lambda$ invalidate inferences based on OLS because coefficient estimates are no longer efficient but remains unbiased.
Equation (1a) is the standard gravity model which

The second form of spatial dependence is the spatial 


\subsection{Data}

We use bilateral trade flows of processed sugar (SITC Rev.3 code 062) from United Nations Commodity Trade Statistics Database (UNCOMTRADE) between 21 OECD countries and Brazil from 1995 to 2007. Brazil is included in the analysis because it is the major sugar exporting country (USDA 2008). GDP data are from the World Bank Development Indicators, and information on distance and common language are obtained from the Centre d'Etudes Prospectives et d'Informations Internationales (CEPII). The market price support (MPS) are drawn from the OECD Trade and Agriculture Directorate. The coefficient estimate on the market price support variable need to be interpreted with caution. The market price support is applied on raw sugar, however the bilateral trade data are on exports of refined sugar. The coefficient on the exporter market price support variable is expected to be negative because subsidies given to sugar growers have been reduced which is transmitted to refining sugar industries via low cost of production, thereby increasing exports. The importer market price support variable is hypothesized to be positive, implying that high level of subsidies to sugar growers increase production cost of refining sugar industries that put a break on their abilities to export, hence increasing imports.

For estimation purpose, Silva and Tenreyro (2006) point out that adding an arbitrary positive constant number to all observations in the presence of zero in the dependent variable lead to inconsistent estimators, because zero may be the result of rounding errors or wrongly recorded. Since we do not have any zero in my dependent variable, we replace the negative value of the MPS by zero and add one to all values in order to take the logarithm.

\section{Empirical Results}

Table 1 displays the results of the standard gravity model and the theoretically-motivated gravity model. In column 1, all coefficients of the standard gravity model are statistically significant and have the correct signs with explanatory power of $51 \%$. Even though coefficients estimates of exporter and importer market price support are statistically significant, the importer market price does not have the correct sign. However, these estimates are not reliable because of the omission of border effects.

In column 2, the estimated coefficient of exporter market price support is negative and statistically significant. This result suggests that a reduction in the level of market price support provided to sugar growers benefits the processed sugar industries through the induced reduction in market prices of raw sugar. Consequently, a one percent decrease in the market price support in exporting countries increases refined sugar exports by 1.7 percent. The estimated coefficient of importer market price support is positive and statistically significant, indicating a higher market price support to sugar growers that increase the price of raw sugar for processed sugar industries. Thus, a one percent increase in the market price support in importing countries increases imports of refined sugar by 3.6 percent. The estimated coefficients on NAFTA and EU are not statistically significant.

Table 2 reports the estimation results of the spatial lag and spatial error model without any fixed effects in column 1-2, while column3-4 include the spatial fixed effects. First we discuss the spatial lag and spatial error model before turning to the spatial fixed effects.

In column 1-2, the estimated coefficients of GDPi and GDPj are positive and statistically significant at the 1 percent level, implying that there is positive relationship between bilateral trade and incomes of partners. The parameter estimate of distance is negative and statistically significant at the 1 percent level. This suggests that as distance increase between countries $i$ and $j$, transaction costs also increase which reduce trade. The estimated coefficients of exporter and importer market price support are statistically significant but do have the correct sign. As expected, common language, EU and NAFTA are positive and significantly impact the volume of trade.

The estimated coefficient $\lambda$ is positive and statistically significant at the 1 percent level in column 1 . This suggests that trade flow in one region is affected by the neighboring regions if these regions trade are above or below "normal" as predicted by the model (Bernat, 1996). In addition, the statistical significance of the autocorrelation coefficient indicates the presence of the non-spherical errors, suggesting a good model specification as opposed to OLS. In column 2, the estimated coefficient of $\rho$ is positive and statistically significant at the 1 percent level. This suggests that trade in one region is affected by the performance of its neighbors exports.

In column 3-4, we remove all time invariant variables and restricting GDP to unitary to run the spatial fixed effect. In column 3 the estimated coefficient $\lambda$ is positive and statistically significant at the 1 percent level, suggesting a good model specification. The coefficient estimate of the exporter market price support is negative and statistically significant, indicating that a one percent reduction in the market price support in exporting countries leads to 0.7 percent increases in exports. The parameter estimate of importer market price support is positive and statistically significant, suggesting that a one percent increase in the market price in importing countries increases the volume of imports of refined sugar by 0.6 percent. The estimated coefficients of NATFA and EU are positive and statistically significant. This indicates that being a member of the EU is associated with an average 134 percent $((\exp (0.85)-1) \times 100)$ increase in refined sugar export relative to non-members, whereas being part of NAFTA is associated with an average 2187 percent ((exp(3.13)-1) $\mathrm{x}$ $100)$ increase in refined sugar exports relative to nonmembers. This finding is consistent with Grant and Lambert (2008) who found that the average effect of RTA increases agricultural trade of members. 
In column 4 , the estimated coefficient of $\rho$ is positive and statistically significant. This implies that a one percent increase in trade in one region causes a 0.45 percent increase of weighted average of neighboring regions exports. This finding suggests that countries geographically close to each other are likely to intensify trade. The coefficient estimated of the exporter market price support is negative and statistically significant, indicating that a one percent reduction in the market price support in exporting countries leads to 0.8 percent increases in exports. The parameter estimate of importer market price support is positive and statistically significant, suggesting that a one percent increase in the market price in importing countries increases the volume of imports of refined sugar by 0.6 percent. The estimated coefficients of NATFA and EU are positive and statistically significant. This indicates that being a member of the EU is associated with an average 132 percent $((\exp (0.84)-1) \times 100)$ increase in refined sugar export relative to non-members, whereas being part of NAFTA is associated with an average 2142 percent $((\exp (3.11)-1) \times 100)$ increase in refined sugar exports relative to non-members.

\section{Conclusion}

In this paper, we investigate the effect of the market price support on trade of refined sugar using the theoretically motivated consistent gravity model and spatial econometric techniques over the period 1995-2002. Estimating the panel gravity model with bilateral pair and country by time fixed effects generates a $1.7 \%$ increase in refined sugar exports, while the spatial lag and spatial fixed effects increase refined sugar exports by $0.8 \%$. The results suggest that the coefficients estimated of the theoretically motivated gravity model overstate trade flows because it fails to account for the spatial dependence across trade flows. This finding justifies the use of appropriate spatial models in which the structure of the spatial dependency is embodied in the weighted matrix to assess the effects of regional trade agreements as well as policy questions. The empirical results indicate that any appropriate effort to reduce market price support, particularly in OECD countries that heavily intervene in the sugar market will increase trade of refined sugar.

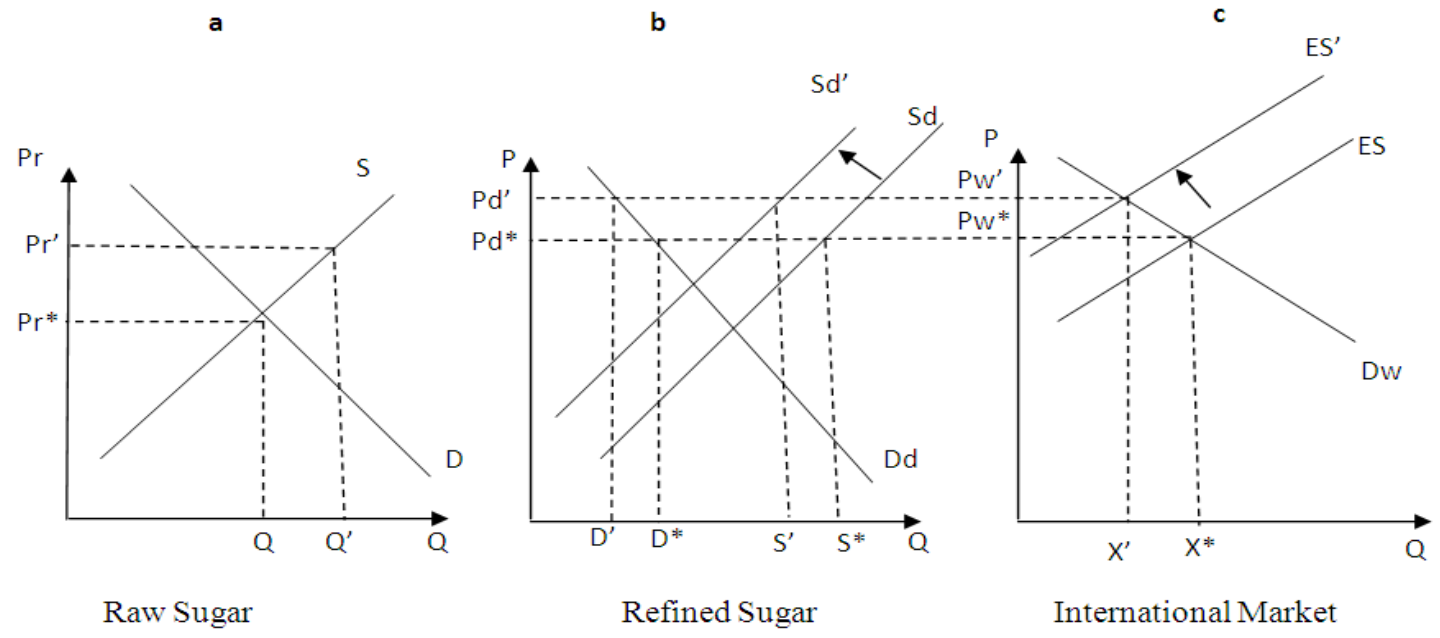

Figure 1. Analysis of the Market Price Support

Table 1. Regression Results of the different Gravity Model Specification

\begin{tabular}{|c|c|c|}
\hline Variables & $\begin{array}{l}\text { (1) } \\
\text { No fixed or time effects }\end{array}$ & $\begin{array}{c}\text { (2) } \\
\text { Bilateral fixed and country-and-time effects }\end{array}$ \\
\hline$G D P_{i}$ & $\begin{array}{l}0.59 * * * \\
(24.14)\end{array}$ & $1.00^{\mathrm{a}}$ \\
\hline$G D P_{j}$ & $\begin{array}{l}0.50^{* * *} \\
(20 . .61)\end{array}$ & $1.00^{\mathrm{a}}$ \\
\hline Dist $_{i j}$ & $\begin{array}{l}-0.87 * * * \\
(-22.70)\end{array}$ & \\
\hline $\operatorname{Lang}_{i j}$ & $\begin{array}{l}0.87 * * * \\
(10.32)\end{array}$ & \\
\hline Border $_{i j}$ & $\begin{array}{c}0.42^{* * *} \\
(4.10)\end{array}$ & \\
\hline$N A F T A_{i j}$ & $\begin{array}{c}0.66^{* * *} \\
(3.34)\end{array}$ & $\begin{array}{l}-0.37 \\
(-1.18)\end{array}$ \\
\hline$E U_{i j}$ & $\begin{array}{c}0.41^{* * * *} \\
(4.82)\end{array}$ & $\begin{array}{l}-0.31 \\
(-1.57)\end{array}$ \\
\hline$M P S_{i}$ & $\begin{array}{c}0.61 * * * \\
(3.35)\end{array}$ & $\begin{array}{c}-1.71 * * * \\
(-2.94)\end{array}$ \\
\hline
\end{tabular}




$\begin{array}{ccc}M P S_{j} & -1.21 * * * & 3.65 * * * \\ \mathrm{R}^{2} & (-6.06) & (6.66) \\ \mathrm{N} & 0.51 & 0.94 \\ & 2574 & 2574\end{array}$

Notes: The numbers in parentheses are $t$-statistics; ${ }^{* *},{ }^{* *}, *$ indicate significance at $1 \%, 5 \%$, and $10 \%$ level, respectively. ${ }^{\text {a } I n d i c a t e s ~ u n i t a r y ~ G D P s ~}$

Table 2.Regression Results of the Spatial Econometrics

\begin{tabular}{|c|c|c|c|c|}
\hline variables & $\begin{array}{c}\text { (1) } \\
\text { Spatial error }\end{array}$ & $\begin{array}{c}\text { (2) } \\
\text { Spatial lag }\end{array}$ & $\begin{array}{c}\text { (3) } \\
\text { Spatial error and spatial } \\
\text { fixed effects }\end{array}$ & $\begin{array}{l}\text { (4) } \\
\text { Spatial lag and spatial fixed } \\
\text { effects }\end{array}$ \\
\hline$G D P_{i}$ & $\begin{array}{l}0.45^{* * * *} \\
(25.66)\end{array}$ & $\begin{array}{l}0.44^{* * * *} \\
(25.52)\end{array}$ & $1.00^{\mathrm{a}}$ & $1.00^{\mathrm{a}}$ \\
\hline$G D P_{j}$ & $\begin{array}{l}0.36^{* * *} \\
(19.16)\end{array}$ & $\begin{array}{l}0.36^{* * *} \\
(19.18)\end{array}$ & $1.00^{\mathrm{a}}$ & $1.00^{\mathrm{a}}$ \\
\hline Dist $_{i j}$ & $\begin{array}{c}-0.94 * * * \\
(-27.45)\end{array}$ & $\begin{array}{l}-0.93 * * * \\
(-27.23)\end{array}$ & & \\
\hline Lang $_{i j}$ & $\begin{array}{l}1.01 * * * \\
(12.61)\end{array}$ & $\begin{array}{l}1.00 * * * \\
(12.50)\end{array}$ & & \\
\hline$N A F T A_{i j}$ & $\begin{array}{c}1.09 * * * \\
(5.58)\end{array}$ & $\begin{array}{c}1.08^{* * *} \\
(5.51)\end{array}$ & $\begin{array}{c}3.13 * * * \\
(15.81)\end{array}$ & $\begin{array}{c}3.11 * * * \\
(15.75)\end{array}$ \\
\hline$E U_{i j}$ & $\begin{array}{l}0.22^{* *} \\
(2.51)\end{array}$ & $\begin{array}{l}0.21 * * \\
(2.50)\end{array}$ & $\begin{array}{l}0.85^{* * *} \\
(10.99)\end{array}$ & $\begin{array}{l}0.84 * * * \\
(10.92)\end{array}$ \\
\hline$M P S_{i}$ & $\begin{array}{c}0.72 * * * \\
(3.92)\end{array}$ & $\begin{array}{c}0.69 * * * * \\
(3.78)\end{array}$ & $\begin{array}{l}-0.76 \\
(-1.59)\end{array}$ & $\begin{array}{l}-0.82^{*} \\
(-1.78)\end{array}$ \\
\hline$M P S_{j}$ & $\begin{array}{c}-0.83 * * * \\
(-4.17)\end{array}$ & $\begin{array}{c}-0.84 * * * \\
(-4.22)\end{array}$ & $\begin{array}{c}0.62 * * * \\
(3.78)\end{array}$ & $\begin{array}{c}0.61 * * * \\
(3.72)\end{array}$ \\
\hline$\lambda$ & $\begin{array}{l}0.33 * * \\
(2.53)\end{array}$ & & $\begin{array}{c}0.52 * * * \\
(5.57)\end{array}$ & \\
\hline$\rho$ & & $\begin{array}{c}0.01 * * * \\
(3.09)\end{array}$ & & $\begin{array}{c}0.45 * * * \\
(4.81)\end{array}$ \\
\hline $\mathrm{R}^{2}$ & 0.49 & 0.49 & 0.56 & 0.57 \\
\hline $\mathrm{N}$ & 2574 & 2574 & 2574 & 2574 \\
\hline
\end{tabular}

Notes: The numbers in parentheses are $t$-statistics; ***,**, * indicate significance at $1 \%, 5 \%$, and $10 \%$ level, respectively.

${ }^{a}$ Indicates unitary GDPs

\section{References}

[1] Anderson James E. 1979. "A Theoretical Foundation for the Gravity Equation.” American Economic Review 69(1): 106116.

[2] Anderson, J.E., and E. Van Wincoop. 2003. "Gravity with Gravitas: A Solution to the Border Puzzle." American Economic Review 93(1):170-92.

[3] Anselin Luc. 1988. Spatial Econometrics: Methods and Models. Kluwer, Dordrecht.

[4] Baier, S. and J. Bergstrand.2007. "Do Free Trade Agreement Actually Increase Memebers'International Trade?" Journal of International Economics 71(1):72-95.

[5] Bergstrand Jeffrey. 1990. "The Hecksecher-OhlinSamuelson Model, the Linder Hypothesis and the Determinants of Bilateral Intra-Industry Trade." The Economic Journal 100(403):1216-1229.

[6] Bernat Andrew. 1996. "Does Manufacturing Matter? A Spatial Econometric View of Kaldor's Laws." Journal of Regional Science, 36(3): 463-477.

[7] Borrel Brent and Pearce David. 1999. "Sugar: The Taste Test of Trade Liberalization."Canberra, Sydney: Centre for International Economics.
[8] Deardorff, A. 1998. "Does Gravity Work in a Neoclassical World?" In J.A. Frankel, ed. The Regionalization of the World Economy. Chicago: University of Chicago Press, 732.

[9] Elhorst Paul and Sandy Freret. 2009. "Evidence of Political Yardstick Competition in France using a Two-Regime Spatial Durbin Model with Fixed Effects." Journal of Regional Science, 49(5): 931-951.

[10] Elobeid Amani and John Beghin. 2006. "Multilateral Trade and Agricultural Policy Reforms in Sugar Markets." Journal of Agricultural Economics 57(1): 23-48.

[11] Koo W. Won. 2002. "Alternative U.S. and EU Sugar Trade Liberalization Policies and Their Implications." Review of Agricultural Economics 24(2): 336-352.

[12] Legg Wilfrid. 2003. " Presidential Address Agricultural Subsidies: Measurement and Use in Policy Evaluation." Journal of Agricultural Economics 54(2):175-201.

[13] LeSage James and Pace Kelly. 2008. "Spatial Econometrics Modeling of Origin-Destination Flows." Journal of Regional Science 48(5):941-967.

[14] Organization for Economic Cooperation and Development (OECD). 2001. Market Effects of Crop Support Measures: Agriculture and Food. OECD, Paris. 
[15] Oskam J. Arie and Gerrit Meester. 2006. "How useful is the PSE in determining agricultural support." Food Policy $31: 123-141$.

[16] Porojan, A. 2001. "Trade Flows and Spatial Effects: The Gravity Model Revisited."Open Economics Review 12(3):265-280.
[17] Silva, J.M.C. and S. Tenreyro. 2006. "The Log of the Gravity" The Review of Economics and Statistics, 88(4): 641-658.

[18] United States Department of Agriculture (USDA). 2010. Sugar: World Production Supply and Distribution. Foreign Agricultural Service/USDA. 